\title{
The Land without God (Země bez Boha)
}

\author{
Author: Ota B. Kraus
}

First Published: 1948

Translation: Hebrew (Adama l'lo elohim, 1953).

\begin{abstract}
About the Author: Ota B. Kraus (1921-2000), originally Otto B. Kraus, a poet, writer, teacher and graphologist, was born into a family of assimilated Jews in Prague. His father was the owner of a factory. Kraus, his parents and his younger brother were deported to the Theresienstadt Ghetto in May of 1942 and from there to Auschwitz-Birkenau in December of 1943, to the so-called Family Camp where the Czechoslovak Jews were located. Kraus was at first forced to work manually, later he became an educator in the Children's Block. In July of 1944, he was deported to the Schwarzheide concentration camp. His father was killed in the gas chamber, his mother and brother died in other camps. Kraus survived the death march to Theresienstadt at the end of the war where he was liberated. After the war he married Dita Polach, a Jewish survivor. In 1949 they emigrated to Israel. They spent a year in the village Shaar Chefer. From there they moved to Givat Chaim kibbutz, next to the Children's Village of Hadassim, and finally they settled in Netanya. In Israel, Kraus first worked as a day labourer, then began farming privately and eventually became a teacher and graphologist. He and his wife visited Prague regularly from 1989 until his death.

In most of Kraus' works, the narratives, motifs as well as the figures are inspired by his friends' and the author's own recollections. After his emigration, he had to change from his native Czech to writing English and therefore most of his works were written in English. This is why his later style was not as brilliant as in The Land without God. Nevertheless, at the same time, it gained a new dimension of detailed descriptions of events (such as in The Painted Wall) and thanks to his life in Israel there is also a broader variety of themes (mainly kibbutz life, mysticism, conversion, assimilation and the Arab-Israeli conflict). Kraus was one of the first Czech authors who introduced Czech readers to the closed world of a kibbutz, the life of the newly settled pioneers and the problems of the new State of Israel (The Wind Blowing from the Mountains and Dispute of Pigs).
\end{abstract}

Further Important Publications: The Dream Merchant and Other Galilean Stories (1991, Czech 2009; short stories); Vitr $z$ hor (1991, The Wind Blowing from the Mountains, novel); Můj bratr dým (1993, literally My Brother, the Smoke, in English translated as The Painted Wall, 1995; novel); Vepři ve při (1993, Dispute of Pigs; novel); My Cancer (2012; autobiography); Cesta pouští (2014, Desert Years; novel).

Ә Open Access. (C) 2021 Hana Hříbková, published by De Gruyter. (cc) BY-NC-ND This work is licensed under a Creative Commons Attribution-NonCommercial-NoDerivatives 4.0 License. https://doi.org/10.1515/9783110671056-056 


\section{Content and Interpretation}

Kraus' major work The Land without God was written within a few months after the end of the war (from autumn of 1945 to July of 1946). A fragment of the manuscript was published, titled Auschwitz, in 1947. The narrative takes place in Auschwitz chronologically, with short retrospective episodes, mainly within the Family Camp, between the 23rd of December, 1943 and July of 1944. The muddy Hell on earth is ruled by the devil Beelzebub and his helpers have turned his face away from this place, where spiders with machine guns, and their caps decorated with death skulls, spin their hellish nets. Filth, sludge and the clay of the earth are overcast by heavy clouds, by wind, rain and snow; the action often takes place at dusk, in darkness, or before sunrise. In the descriptions of the place, where people are dying every day, grey, black or the crimson colours are used, referring to the colours of Hell (black walls, the black Prince Beelzebub, black fear, crimson railway station roof, blood-coloured sun, crimson moon, grey mornings, orange flames etc.). The life span of the people is limited and cannot be extended, they have been granted a period of six months, after which they are expected by Death in the gas chambers.

The narrator's descriptions are interspersed with many dialogues and inner monologues. A lot of characters appear in the novel, most of them are assimilated Jews. They are only minimally characterised (often, only the eyes are described, unfavoured people are "well fed", sometimes their former profession is mentioned). They find themselves caught in an extreme situation, where their survival depends on chance, on their will for life and on rejecting usual social conventions under the conditions dictated by Beelzebub. The degradation and the extreme conditions cause squabbles among the characters. The main hero is a young man named Daniel, who at the end of the novel is selected for deportation to another "Hell" with a group of other prisoners, while the remaining prisoners are led to their death. The strongly negative character is the hangman Maxa, described in more detail.

The author used his own experiences as a prisoner as well as those of his close friends. In the novel, the writer utilised metaphors, expressive words, poetic similes and personifications to describe the "undescribable" (see also $\rightarrow$ Colors written by Jiři Weil). To these devices also belong allusions to the Hebrew Bible in the novel.

Some decades later Kraus returned to the same events in the novel The Painted Wall (1993), formerly titled The Diary. However, it was written in a different literary style (impersonal descriptions, a more distant view, stark language without poetic ornamentation). On the contrary, in the novel Desert Years the author used metaphoric and symbolic devices again.

In The Land without God, author's play with the names of characters can be found, mainly from the Bible. It was later utilised also in The Dream Merchant and Other Galilean Stories as well as in Dispute of Pigs.

The Land without God contains a wealth of descriptions of strong emotions - anger, doubt, fear, loss of integrity, betrayal, hate, despair. There is also sarcasm and irony. People face their imminent death not with pride and with a song, but with lamen- 
tation, dread and helplessness (compare also Jiři Weil's $\rightarrow$ Elegy for 77297 Victims). The characters in the novel are prototypes who speak for the thousands of others whose fate is similar. Their position in the hierarchy of the concentration camp, higher or lower, is not the result of their own volition, but of pure chance and a change of values, which is dictated by the circumstances. For instance, a humiliated dancing girl passes the selection and is sent to work in Germany, although she has neither the training nor the strength for physical work.

Kraus' ability to interpret his personal experiences of the Holocaust horrors in an original literary form, with distance, in symbolic scenes, yet imbued with emotional intensity, preceded its time in many ways. It put Kraus on a level of experienced belletrists, such as Jiři Weil, or later the younger talented Arnošt Lustig, who like Kraus was himself interned in Auschwitz.

\section{Main Topics and Problems}

The dominant topics in the novel The Land without God are the Shoah in Auschwitz, and the loss of identity, or rather loss of human decency in extreme situations.

Kraus also focused on the theme of the Shoah in the above mentioned The Painted Wall, in the poem The Window (Okno), composed while he was on a hunger march, and in part in the novel Desert Years. This work takes place predominantly in prewar Czechoslovakia, dealing among others with the persecution of the Czech Jewish population.

The topic of identity, or rather the search for identity, can be found throughout almost the entire body of the author's work. It appears in all his literary genres and often is connected with the traditional literary plot, such as the clashing opinions between father and son. In Kraus' work it is often connected to religion - leaving home due to religious conflicts (the desire to work in the Holy Land), conversion (a Jew becoming a Catholic and vice versa), abandoning of Jewish orthodoxy, joining a kibbutz, loss of faith, or in reverse, becoming religious. It is also sometimes connected with a visionary theme, the notion of building the Jewish state. A possible reason might be the fact that the author himself lacked the feeling of being anchored in a national and religious identity.

In The Land without God Kraus describes a change of identity not in individual characters, but also in crowded scenes (for instance, a group of women whose behaviour changes due to circumstances and sinks to animal instincts). People react in different ways to the extreme inhuman conditions of suffering, to the impossibility of escaping horrific confinement, to the loss of human rights and dignity, to imminent death. Some react by denying, others by hoping for a quick end of the war, seeking strength from God. Some reflect on the meaning of life, beauty and goodness, others resign to their fate or try to organise a resistance, to plan an escape, search for intimacy without love. Some spin fantastic solutions while others wallow in tears and desperation. Some characters become indifferent to their fate or the death of others and do anything to survive (they steal from the newcomers and from the dead). The 
animal instinct of survival prevails over moral precepts, or even family bonds. Children also are marked by Satan and lose their innocence.

A prominent aspect of the novel is laughter - bitter or relieving laughter eventually the liberating laughter after some stress, laughter of kindness and laughter that hides the true state of mind. The author often uses images of roads in connection with hope and death (as well as in his other works). The Land without God begins and ends with transports, "the road to the unknown", building the road in Auschwitz is part of the narrative, and its completion leads to the selection and dismantling of the camp.

\section{Cited Work}

Kraus, O. B. (1992). Země bez Boha. Praha: Sefer.

\section{Further References}

Bednář, K. (1948). Nad první knihou Oty B. Krause. In: O. B. Kraus, Země bez Boha. Praha: Václav Petr, pp. 7-10. Halamová, M. (2015). Krausova iluze autentičnosti. Literární archiv, (47), pp. 175-197. Hříbková, H. (2014). Ota B. Kraus’s Life and his Novel Můj bratr dým (The Painted Wall). In: R. Ibler, ed., Der Holocaust in den mitteleuropäischen Literaturen seit 1989. Stuttgart: ibidem, pp. 203-214. Hříbková, H. (2016). Svět kibucu a holokaust očima Oty B. Krause. In: J. Holý, ed., Cizí i blízcí. Židé, literatura, kultura $v$ českých zemích ve 20. století. Praha: Akropolis, pp. 729-760. Kraus, O. B. (1947). Osvětim. In: Ohnice 1. Sborník současné literatury. Praha: Václav Petr, pp. 13-19. Kraus, O. B. (2012/ 2013). Moje rakovina. Židovská ročenka, 5773, 59, pp. 150-158. Krausová, D. (2009). Úhelný kámen: o autorovi „Galilejských povídek“ s Ditou Krausovou. Roš chodeš, 71 (7), pp. 6-7. Krausová, D. (2018). Odloženýživot. Skutečný př́běh osvětimské knihovnice. Praha: Ikar. Pojar, M. (2007). Ota B. Kraus. In: F. Skolnik, ed., Encyclopaedia Judaica, vol. 12, p. 342. Available at: http://www.jevzajcg.me/enciklopedia/Encyclopaedia\% 20Judaica,\%20v.\%2012\%20(Kat-Lie).pdf [Accessed: 06.02.2020] Stránský, P. (1999). Poslové obětí. Praha: Perla. Stránský, P. (2000). Ota B. Kraus. Roš chodeš, 11(12), p. 11.

\section{Other Resources}

Dita Kraus's Private Archive, Netanya, Israel. Literární archiv Památníku národního písemnictví (Museum of Czech Literature), Prague, Collection Ota B. Kraus. Bejt Terezin Archive, Israel.

$\mathrm{HH}$ 